Dariusz Ambroziński

Uniwersytet Warmińsko-Mazurski

Wydział Nauk Ekonomicznych

Katedra Analizy Rynku i Marketingu

dambrozinski@gmail.com

\title{
Wspólnoty intencjonalne jako przykład alternatywnego stylu życia
}

\author{
Artykuł nadesłany: 1 czerwca 2017 r.; artykuł zaakceptowany: 15 grudnia 2017 r. \\ JEL Classification: P48, Q01, Q56
}

Keywords: lifestyle, intentional communities, consumerism, sustainable development, ecovillage

\begin{abstract}
Intentional communities as an example of an alternative lifestyle

Contemporary society is living in times of significant cultural changes, which is a consequence of technological development, globalization and social awareness. Distributed by mass media and producers consumerist lifestyle are no longer attractive to society. The result is an attempt to find an alternative. The gradual transformation of value systems often leads to choices that correspond to the concept of sustainable development. Society (community), cultural (spiritual) and ecological integration is realized by intentional communities. The most popular types of such housing community are ecovillages, and cohousings. Choosing the location and form of residence is a decision that affects the quality and style of life. Rebuilding your own lifestyle in line with the idea of sustainable development is a very difficult transition. The easiest way for society is submission to consumerism. This means that an in-depth analysis of own needs is required and often resignation of the desires, comforts and other amenities that are preferred over the common good. The importance of the problem is emphasized by the increasing demands of society that sustainable development is not a choice and a necessity leading to an improvement in the quality of life of present and future generations. The article attempts to present a new approach to sustainable development as an alternative to the consumerist lifestyle, in addition to identifying the types of intentional communities and assessing their development prospects.
\end{abstract}

\section{Wstęp}

Uważa się, że styl życia jest bardzo ważnym czynnikiem wpływającym przede wszystkim na zdrowie, ale też na rozwój społeczny i gospodarczy. Terminem tym określa się ogół cech, które są charakterystyczne dla zachowania jednostki bądź 
zbiorowości. Ujawniają się one każdego dnia, podczas codziennej egzystencji, w szczególności w konsumpcji, sposobach spędzania wolnego czasu, stosunkach międzyludzkich i postawach wobec pracy.

Niestety u większości społeczeństwa obserwowany jest styl życia odznaczający się nadmierną konsumpcją, pośpiechem, stresem czy brakiem aktywności fizycznej. Wpływ na to ma wiele procesów, spośród których można wyróżnić między innymi rozwój kapitalizmu, będącego dominującym systemem ekonomicznym, globalizację, zmniejszające się znaczenie tradycji w życiu codziennym, przemiany w organizacji społecznej oraz wspólnotowości. Ludzie stają się indywidualistami stawiającymi dobro własne ponad dobro wspólne. Interesuje ich wyłącznie teraźniejszość, a nie przyszłość. Prowadzi to do ogromnej degradacji środowiska, które powinniśmy przekazać kolejnym pokoleniom w jak najlepszym stanie. Rozpowszechniany również przez środki masowego przekazu oraz producentów konsumpcjonistyczny styl życia staje się jednak coraz mniej atrakcyjny dla społeczeństwa (Kłos 2014, s. 5).

Celem niniejszego artykułu jest przedstawienie wspólnot intencjonalnych jako alternatywnego stylu życia oraz zrównoważonej konsumpcji, która zyskuje coraz większą popularność zarówno wśród konsumentów, jak i producentów. $Z$ założenia ma ona odwoływać się do koncepcji zrównoważonego rozwoju i stanowić alternatywę dla konsumpcjonizmu, której efektem ma być zredukowanie negatywnych społecznie i ekologicznie efektów kultury konsumpcyjnej (Neale 2015, s. 141).

\section{Teoretyczny aspekt badań}

Wspólnoty intencjonalne jako forma stylu życia są dość nowym zjawiskiem. Temat ten jest dopiero zgłębiany przez badaczy, w związku z czym dostępnych jest niewiele źródeł danych. Jednak jest on bardzo aktualny i coraz bardziej zyskuje na popularności. Szczególnie w odniesieniu do poruszanej w artykule koncepcji zrównoważonego rozwoju. Obecny styl życia większości społeczeństwa prowadzi do produkcji ogromnych ilości odpadów i zanieczyszczeń, które bardzo niekorzystnie wpływają na środowisko naturalne. Zgodnie z koncepcją zrównoważonego rozwoju otaczająca nas przyroda oraz jej bogactwa powinny wystarczyć również przyszłym pokoleniom, dlatego obecnie duży nacisk kładzie się na rozsądne gospodarowanie zasobami. Funkcjonowanie wspólnot intencjonalnych może znacząco przyczynić się do realizacji tego celu.

\section{Wspólnoty intencjonalne}

Przed przejściem do szczegółowego omówienia wspólnot intencjonalnych, najpierw należy zadać sobie pytanie: czym właściwie są wspólnoty? Pierwsze, co przychodzi na myśl, to różnego rodzaju wspólnoty religijne lub mieszkaniowe. 
Jednak szukając informacji na ten temat od strony nauk społecznych, można znaleźć termin sformułowany ponad sto lat temu przez niemieckiego socjologa Ferdynanda Tönniesa. Według niego wspólnota tworzona jest w oparciu o relacje zachodzące pomiędzy jej członkami, wynikające z ich całkowitego zaangażowania w działania, które często są oparte na tradycji. Zgodnie $\mathrm{z}$ tą teorią każda wspólnota będzie istnieć tak długo, jak będą chcieli tego jej członkowie, i będzie na tyle trwała, na ile będą się oni zgadzać w podejmowaniu decyzji dotyczących wspólnego dobra. Tönnies uważał, że o powstaniu i utrzymywaniu się wspólnoty decyduje chęć jej uczestników do współbycia (Wolska 2015, s. 3).

Zgodne z teorią Tönniesa jest powstawanie i funkcjonowanie wspólnot intencjonalnych. Są one dobrowolnymi, oddzielonymi od reszty społeczeństwa i zaplanowanymi grupami ludzi, którzy podjęli decyzję, aby razem żyć lub pracować w celu realizacji wspólnie określonego ideału lub wizji. Większość z nich dzieli ten sam obszar i budynki mieszkalne. Członków wspólnoty zazwyczaj łączą te same wartości, zasady moralne czy wyznawana religia, jednak zdarza się również, że mają oni odmienne poglądy. Część grup posiada wspólne zasoby oraz dzieli się obowiązkami i pracami wewnątrz swojej społeczności (Moss Kanter 1973, s. 15-18; Kozeny 2005, s. 11-14).

Najważniejszymi cechami charakterystycznymi dla tworzenia, kształtowania i funkcjonowania wspólnoty intencjonalnej są:

— współudział mieszkańców w projektowaniu i budowie osiedla oraz jego podział na sfery publiczne i prywatne;

— współwłasność części dóbr, zarówno zastanych (ziemia, budynki), jak i nabytych (na przykład produkty spożywcze);

— projektowanie przestrzeni mieszkalnej w taki sposób, aby ułatwiała interakcje członków grupy;

- wspólne zarządzanie oraz brak hierarchiczności we wspólnocie (McCament, Durrett, Hertzman 1994, s. 38).

Spośród różnych przykładów wspólnot intencjonalnych można wyróżnić następujące typy (w artykule skupiono się tylko na dwóch pierwszych):

- cohousingi (nazwa pochodzi od połączenia słów community housing „wspólnotowe zamieszkiwanie”) - polegają na intencjonalnym budowaniu osiedli i tak zwanym planowanym sąsiedztwie, w którym uwagę skupia się głównie na społecznym aspekcie takiego mieszkania. Członków cohousingów charakteryzuje mniej intensywny sposób życia jako grupy oraz mniejsze zintegrowanie w porównaniu z innymi typami wspólnot;

— domy kooperatywne - prowadzony w nich tryb życia odznacza się bardziej intensywną formą. Ich mieszkańcy wyrażają tę samą ideologię, która bardzo często wpływa zarówno na ich życie codzienne, jak i wspólne organizowanie czasu wolnego;

— ekowioski (wioski ekologiczne) — rodzaj wspólnot intencjonalnych zakładanych na terenach wiejskich. Budynki mieszkalne na ich obszarach są pro- 
jektowane i wykonywane tylko z materiałów przyjaznych dla środowiska. $\mathrm{Na}$ terytorium ekowiosek uprawiana jest ziemia, jednak ma ona przynosić wyłącznie pożywienie niezbędne dla mieszkańców wspólnoty. Wszystkie czynności, które są wykonywane przez ich mieszkańców dla społeczności, są bezpłatne (Christian 2003, s. 15).

\subsection{Cohousing}

Cohousing to określenie dla wspólnotowego rodzaju zamieszkiwania, będącego odpowiedzią na zjawisko alienacji w miejscach zamieszkania, w których nikt nie zna swoich sąsiadów, w wyniku czego nie istnieje poczucie wspólnoty społecznej. Miał on swoje początki w latach sześćdziesiątych XX wieku w Danii, a do Ameryki Północnej dotarł pod koniec lat osiemdziesiątych. Osiedle cohousingowe złożone jest $\mathrm{z} \mathrm{w}$ pełni samodzielnych, prywatnych mieszkań, ale posiada również powierzchnie zbiorowe, na przykład wspólną dużą kuchnię, pokój spotkań, miejsce rekreacji, wypoczynku, warsztat, bibliotekę czy miejsce zabaw dla dzieci. Przestrzeń wspólna daje możliwość pogłębiania życia społecznego poprzez organizację spotkań (zarówno formalnych, dotyczących na przykład planowania zabudowy, jak i towarzyskich), opracowywanie różnego typu projektów, budowanie przestrzeni oddzielonej od ruchu samochodowego i zachęcającej do relacji międzyludzkich. Typowa wspólnota liczy zazwyczaj od 20 do 30 jednorodzinnych domów bądź lokali mieszkalnych. Zabudowania są zwykle usytuowane wokół wspólnego placu głównego lub wzdłuż uliczki dla pieszych. Zwykle takie wspólnoty są planowane, a następnie zarządzane przez ich członków. Jest to przykład zamierzonego sąsiedztwa (Idem 2009, s. 25; Wolska 2014, s. 13).

Wspólnoty cohousingowe charakteryzują następujące cechy (Wolska 2014, s. 13-22):

— cel utworzenia grupy - idea bez ideologii — członkowie wspólnoty organizują się i integrują w imię idei alternatywnego stylu życia, jednak nie łączy ich żadna, wspólna ideologia czy wyznawany kult;

- partycypacja przyszłych mieszkańców w procesie projektowania i budowy osiedla — osoby chcące zamieszkać w cohousingu spotykają się i współpracują jeszcze przed powstaniem osiedla;

— celowo zaprojektowana przestrzeń mieszkalna — podział na zabudowania prywatne i wspólne. Przestrzeń osobista zapewnia poczucie odosobnienia, co paradoksalnie wpływa pozytywnie na kształtowanie stosunków międzyludzkich (Simmel 1975, s. 152-154);

— wspólne udogodnienia — z wszelkiego rodzaju przedmiotów, narzędzi czy pomieszczeń grupowych mogą korzystać wszyscy członkowie cohousingu;

— wspólne zarządzanie posiadłością — decyzje dotyczące wspólnoty podejmowane są przez ogół mieszkańców; 
— brak hierarchii w grupie — wszyscy członkowie cohousingu są równi i w takim samym stopniu zobligowani są do ponoszenia odpowiedzialności za miejsce, w którym mieszkają, i angażowania się w jego rozwój;

— niezależność finansowa każdego mieszkańca - wspólnota nie jest źródłem dochodów, czynności wykonywane przez członków grupy na terenie osiedla nie są opłacane.

\subsection{Ekowioski}

Wioski ekologiczne to rodzaj wspólnoty intencjonalnej, których członkowie prowadzą bardzo wyraźnie zrównoważony, ekologiczny styl życia. Najczęściej są one tworzone na obszarach wiejskich, jednak występują również wśród społeczności miejskich. System zabudowy ekowiosek tworzony jest przy zachowaniu tak zwanej ludzkiej skali. Oznacza to, że nie ma nadmiernej rozbudowy. Budynki mają rozmiar i powierzchnię wyłącznie niezbędną do życia i codziennego funkcjonowania, przez co wpisują się w naturalny krajobraz. Ideą mieszkańców wiosek ekologicznych jest prowadzenie zrównoważonego stylu życia. Starają się, aby wszystkie wykonywane przez nich czynności były przyjazne i zintegrowane z naturą. Prowadzą uprawy ekologicznej żywności, którą wykorzystują na własne potrzeby, dzięki czemu ograniczają ilość odpadów i zanieczyszczeń. Mieszkają w domach zbudowanych z naturalnych materiałów, w których wykorzystywane są rozwiązania pasywne oraz solarne, dzięki czemu na własne potrzeby wytwarzają energię odnawialną (Christian 2007; Idem 2009, s. 25).

Ekowioski bywają zróżnicowane, w zależności od tego, jakie idee reprezentują członkowie wspólnoty. Niektóre nawiązują do permakultury, inne do antropozofii czy kibucu. Pomimo różnic osady te powstają na całym świecie. Przykładami są: izraelskie kibuce Ketura lub Lotan, Cristall Water Permaculture Village, Camphill Solborg w Norwegii, szkockie Findhorn czy amerykańskie Twin Oaks (Idem 2009, s. 25).

\section{Konsumpcjonizm a alternatywny, zrównoważony rozwój - wspólnoty intencjonalne}

Koncepcja zrównoważonego rozwoju odegrała ogromną rolę w kształtowaniu formy, w jakiej myśli się obecnie o wzajemnych stosunkach, które występują między gospodarką, społeczeństwem a środowiskiem naturalnym. Dzięki niej zaczęto zastanawiać się, jakie jest miejsce człowieka na ziemi i w rzeczywistości, która go otacza. Nowe spojrzenie na alokacje człowieka w biosferze uświadomiło społeczności konieczność dokonywania zmian (Mazur-Wierzbicka 2005, s. 33).

Coraz więcej osób poszukuje alternatywy do obecnie prowadzonego, konsumpcyjnego stylu życia, ponieważ zauważa jego negatywne aspekty. Stopniowa 
przebudowa systemu wartości prowadzi często do wyborów, które są powiązane z koncepcją zrównoważonego rozwoju. Idea ta mówi o jednoczesnym rozwoju społecznym, ekonomicznym oraz ekologicznym. Postęp w sferze jednego wymiaru nie odbywa się jednak kosztem innego - rozwijają się wspólnie. Jest to proces zaspokajania potrzeb społeczeństwa w taki sposób, aby nie ograniczać możliwości przyszłych pokoleń. Integracja w wymiarze kulturowym, ekologicznym oraz społecznym realizowana jest właśnie we wspólnotach intencjonalnych (zob. rysunek 1). Uwidacznia się między innymi poprzez współżycie z członkami wspólnoty, silne relacje międzyludzkie oraz zależności, które między nimi występują, wspólne pozyskiwanie surowców czy współdzielenie dóbr. Ważnym elementem jest również dbałość o środowisko. Ekologiczne sposoby budowania czy świadomie planowana przestrzeń ograniczają ilość zużywanej przez nich energii. Wykorzystywanie energii solarnej, mniejsza produkcja odpadów oraz recykling w znacznym stopniu zmniejszają emisję zanieczyszczeń w porównaniu z gospodarstwami domowymi żyjącymi konwencjonalne (Wolska 2015, s. 8).

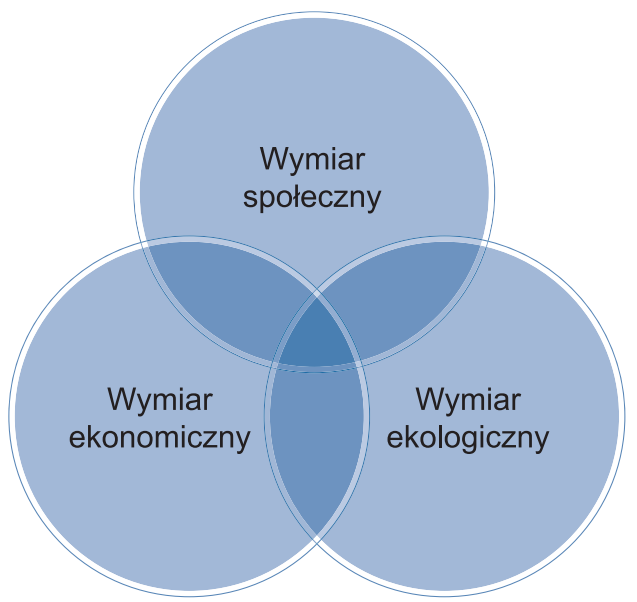

Rysunek 1. Koncepcja zrównoważonego rozwoju

Źródło: opracowanie własne.

Zgodnie z danymi, które zostały przedstawione przez magazyn „Forbes”, zużycie energii przypadające na jednego członka wspólnoty intencjonalnej jest o około 40\% mniejsze niż przeciętnego Amerykanina żyjącego w domu jednorodzinnym. Dodatkowo w uprawach, które prowadzą, nie stosują środków ochrony roślin i nawozów (Eaves 2008, s. 5).

Decyzja dotycząca formy oraz miejsca zamieszkania ma istotny wpływ na styl życia oraz jego jakość. Zmiana dotychczasowego stylu na utożsamiający się z ideą zrównoważonego rozwoju bywa bardzo trudna. Łatwiejsza dla ludzi jest uległość wobec konsumpcjonizmu, będącego jedną z chorób cywilizacyjnych dzisiejszego społeczeństwa. Jest on powiązany z hedonizmem materialistycznym — doktryną 
etyczną, według której najwyższym celem, dobrem oraz podstawowym motywem postępowania ludzi jest przyjemność. Wynika z tego, że w konsumpcjonizmie sama konsumpcja jest stylem życia, a postawę osoby działającej w ten sposób cechuje próżność i egoizm oraz myślenie wyłącznie o teraźniejszości i własnych potrzebach, a nie o przyszłości i wspólnym dobru (Leszczak 2012, s. 15-35). Jest to zupełnym przeciwieństwem koncepcji zrównoważonego rozwoju, która zakłada nie tylko korzyści krótkoterminowe danych działań, lecz także ich wpływ na późniejsze horyzonty czasowe. Oznacza to, że decyzje podejmowane teraz rozważane są również w kontekście przyszłych pokoleń i środowiska, w jakim będą żyć (Birnbacher 1999, s. 30).

\section{Wnioski}

Współcześnie najczęściej spotykanym stylem życia jest konsumpcjonizm. Jednak skutki takiej postawy są bardzo negatywne, zarówno dla środowiska - w wyniku intensywnego wydobywania i zużywania surowców naturalnych, produkcji ogromnych ilości odpadów czy zanieczyszczeń, jak i dla całego społeczeństwa - ludzie stają się indywidualistami, alienują się od innych, w następstwie czego zanikają relacje i kontakty międzyludzkie. Nadmierne wykorzystywanie i degradacja otaczającej nas przyrody oznacza, iż przyszłe pokolenia nie skorzystają $\mathrm{z}$ wielu dostępnych dziś bogactw naturalnych. Będą zmuszone żyć w dużo gorszych warunkach, niż ma to miejsce obecnie. Część społeczeństwa zaczyna sobie to uświadamiać, czego efektem jest sprzeciw wobec dotychczasowego postępowania i poszukiwanie innych rozwiązań.

Jedną z odpowiedzi na takie postawy mogą być wspólnoty intencjonalne, będące alternatywnym w stosunku do konsumpcjonizmu stylem życia. Ich założenia opierają się na koncepcji zrównoważonego rozwoju, która zakłada gospodarowanie dostępnymi zasobami w taki sposób, aby wystarczyły również dla kolejnych pokoleń. Jest to jedyne rozwiązanie pozwalające zachować świat w obecnym kształcie. Cieszy fakt, że teoria ta jest coraz częściej zauważana i stosowana nie tylko przez mieszkańców wspólnot intencjonalnych czy zwykłych członków społeczeństwa, lecz także przez przedsiębiorstwa.

Należy jednak zaznaczyć, że życie we wspólnocie intencjonalnej nie jest dla każdego. Funkcjonowanie w takiej grupie różni się od standardowego życia, co bardzo często wiąże się z koniecznością zmiany samego siebie — swoich postaw, zachowań czy przyzwyczajeń. Odejście od konsumpcyjnej, hedonistycznej postawy wymaga dogłębnej analizy własnych potrzeb. Często wiąże się to z rezygnacją z pragnień, udogodnień czy komfortów, które do tej pory były przedkładane ponad dobro wspólne.

Trudno przewidzieć, jak potoczą się w przyszłości losy wspólnot intencjonalnych, czy społeczeństwo przyszłości będą tworzyć sąsiadujące, kooperatywne 
osiedla lub osady mieszkalne. Obecnie są one jednak bez wątpienia ważnym głosem podczas dyskusji nad wyglądem przyszłego społeczeństwa i jedną z alternatyw, które można wybrać; być może staną się pierwszym krokiem do przejścia cywilizacji w inne fazy rozwoju. Waga problemu podkreślana jest również przez to, że często stawiane są postulaty, iż rozwój w zrównoważony sposób nie jest już tylko jednym z wyborów, a koniecznością i jedynym wyjściem prowadzącym do poprawy jakości życia zarówno obecnych, jak i przyszłych pokoleń.

\section{Bibliografia}

Birnbacher D. (1999), Odpowiedzialność za przyszłe pokolenia, Warszawa.

Christian D.L. (2003), Creating a Life Together. Practical Tools to Grow Ecovillages and Intentional Communities, Gabriola Island.

Christian D.L. (2007), Finding Community. How to Join an Ecovillage or Intentional Community, Gabriola Island.

Eaves E. (2008), Ecotopia, 4 października, https://www.forbes.com/2008/04/10/enviromental-utopias-communities-oped-utopia08-cx_ee_0410ecotopia.html (dostęp: 21.05.2017).

Idem R. (2009), Wspólnota mieszkańców - $\bar{P} A S S E ́$ ?, „Architecturae et Artibus” 1 (2), s. 23-29. Kłos J. (2014), Zjawisko zdrowego stylu życia we współczesnym społeczeństwie polskim, Poznań.

Kozeny G. (2005), In community, intentionally. Communities directory: A guide to intentional communities and cooperative living, „Fellowship for Intentional Communities” nr 3, s. 12-17.

Leszczak O. (2012), Paradoksy konsumpcjonizmu. Typologia i lingwiosematyka, „The Peculiarity of Man" 15, s. 9-35.

Mazur-Wierzbicka E. (2005), Koncepcja zrównoważonego rozwoju jako podstawa gospodarowania środowiskiem przyrodniczym, [w:] Funkcjonowanie gospodarki polskiej w warunkach integracji i globalizacji, red. D. Kopycińska, Szczecin, s. 33-44.

McCamant K., Durrett C., Hertzman E. (1994), Cohousing. A Contemporary Approach to Housing Ourselves, wyd. 2, Berkley.

Moss Kanter R. (1973), Communes: Creating and Managing Collective Life, New York.

Neale A. (2015), Zrównoważona konsumpcja. Źródła koncepcji i jej zastosowanie, „Prace Graficzne" 141, s. 141-158.

Simmel G. (1975), Socjologia, Warszawa.

Wolska A. (2014), Habitat StartUp KIT, Kraków.

Wolska A. (2015), O wspólnotach inaczej. ,Wspólnoty intencjonalne” jako nowa metoda planowania przestrzeni mieszkaniowej zgodnie z założeniami idei zrównoważonego rozwoju, https:// cohoto.net/ahaaa/29 (dostęp: 18.05.2017).

Ekonomia - Wroclaw Economic Review 23/4 (2017)

(C) for this edition by CNS 